\title{
咽喉頭異常感症と胃・十二指腸粘膜病変
}

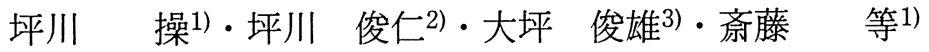

\section{Relation between Abnormal Sensation in the Throat and Gastroduodenal Disease}

\author{
Misao Tsubokawa and Hitoshi Saito \\ (Fukui Medical School) \\ Toshihito Tsubokawa \\ (Tsubokawa ENT Clinic) \\ Toshio Otsubo \\ (Matsunami General Hospital)
}

The stomach and duodenum of 76 patients with abnormal sensations in the throat were examined by esophagogastroduodenal panendoscopy, and the results were compared with those of 91 patients with abdominal complaints. Of the 76 patients, 10 patients $(13.0 \%)$ had severe gastric or duodenal disease (gastric ulcer, duodenal ulcer or verrucous gastritis), 35 patients $(46.0 \%)$ had slight disease (erosive gastritis, duodenitis or gastric duodenal ulcer scar), and 29 pateints (38.0\%) were normal.

Antiulcer drugs were significantly effective in alleviating the abnormal sensation in the throat in patients with severe gastric or duodenal disease, but had only a placebo effect in patients with slight disease. An abnormal sensation in the throat may be induced by hyperconstriction of the cervical muscles through central reflex of the vagus nerve, which is stimulated by gastroduodenal disease.

Key words: abnormal sensation in the throat, gastric disease, duodenal disease, panendoscopy

はじめに

咽喉頭異常感症は，外来診療に抢いて日常認 められる頭痛症や腹痛症などと同じく, 症状病 名の疾患であり, 消炎剂122), 精神安定剂22 4), 抗アレルギー剂(5)などの投与が効果をあげてい るが，難治例に遭遇することも少なくない，そ の成因は多岐にわたり, 疾患の治療効果により
異常感の改善が認められることによって判定さ れることが妥当と考えられ6)，局所的，全身的， 精神的要因がこれまで数多く検討されているが， 成因決定に決め手をかく症例もまた少なくない， また，局所的要因としては，咽喉頭部拈よび隣 接部位に関しての報告がほとんどであり，これ 以外の部位に関しては胃疾患や高血圧との関係

1) 福井医科大学耳鼻咽喉科学教室

2）坪川医院耳鼻咽喉科気管食道科（福井市）

3）松波総合病院耳鼻咽喉科 
が若干報告されているものの報告数は少な $($ (6) 13$)$

今回われわれは，咽喉頭異常感症患者に上部 消化管内視鏡検查を行い，胃・十二指腸粘膜病 变を詳細に検討し，抗潰瘍剤による治療を行い 若干の知見を得たので報告する.

\section{検査対象}

対象は平成 3 年 3 月より 11 月までに咽喉頭異 常感を訴兄て耳鼻科受診し, 頭頸部, 咽院頭部 に腫瘍，形態異常のない患者で，上部消化管内 視鏡検査を施行した76名である。

また，平成 3 年 3 月に消化器症状を訴元て内 科を受診し，上部消化管内視鏡検査を施行した 患者91名を対照として内科受診群とした（表 1 ).

\section{方 法}

電子内視鏡 GIF-XV10 (オリンパス K.K) ま たは，GIF-X10 (オリンパス K.K) を用いて， 上部消化管内視鏡検査を施行した.内視鏡検査 にあたっては，的確な診断を得るために経験豊 富な内科医と共に検査を行った．臨床診断に関 しては, 病理学的検査を施行したものには病理 学的診断を優先し，施行しなかったものには内 視鏡的に診断した。これらの結果を，胃粘膜病 変の程度により, 病態を正常群, 軽症群, 重症

\section{表 1 対 象}

咽喉頭異常感症群:

平成 3年3月より11月までに咽喉頭異常感を訴えて

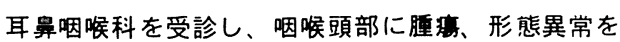
認めない患者 76 名

(男性 37 名、女性 39 名、平均年路 49 歳) 内科受診群 (対照群)：

平成 3 年 3 月に、消化器症状を訴えて内科を受診し、 上部消化管内視鏡検查を施行した 91 名

(男性 49 名、女性 42 名、平均年龄 49 歳)

表 2 胃・十二指腸粘膜病変の分類

正常群：異常なし、周ポリープ、萎縮性周炎，表層性胃炎

軽症群：ひらん性月炎、十二指腸炎、胃・十二指腸潰淟般痕

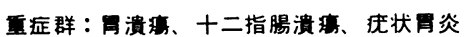

群の 3 群に分け（表 2 ），性別，年歯別につい て検討した，病態の基準は，異常なし，一般に 無症状であると考えられている胃ポリープ，萎 縮性胃炎などを正常群とし，疮状胃炎以外のび

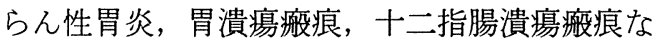
どを軽症群とし, 病変が粘膜下層におよぶ胃潰 瘍，および十二指腸潰瘍，びらん性胃炎のうち 炎症症状が長期間続くことにより生じるといわ れている病状胃炎, および胃ガンを重症群とし た。

今回，食道病変については，咽喉頭異常感症 群が多い傾向を示したものの，症例数が少ない ため検討しなかった。

咽喉頭異常感症群で胃・十二指腸病変を認め た患者35名中28名に，抗潰瘍剤シメチジン 1 日 $600 \mathrm{mg}$ 扎よびセトラキサート塩酸塩 $600 \mathrm{mg}$ を 1 〜 週間投与した. 治療効果は表 3 のごと く患者の自覚症状で判定し，改善以上を有効と した.

\section{結 果}

咽喉頭異常感症群の上部消化管内視鏡検査の 結果は, 正常群29名 (39\%), 軽症群35名（47 $\%)$ ，重症群10名（14\%）であった．同様に内 科受診群では，正常32名 (38.5\%)，軽症群36 名 (36.3\%), 重症群22名（24.2\%）であり（表 4 ), 咽喉頭異常感症群, 内科受診群ともに約 $60 \%$ の胃, 十二指腸病変を認めたが, 病変の程 度としては, 内科受診群の方に重症群が多かっ た。

咽喉頭異常感症群に护ける抗潰瘍剤の効果は, 軽症群で21名中の 4 名 (19\%) が有効, 重症群

\section{表 3 有効度の評価}

\begin{aligned} \hline \hline 治瘾 & 症状が完全に消失したもの \\ 改善 & 症状が気にならなくなったもの \\ やや改善 & 少し良くなったか、まだ気になるもの \\ 不変 & 変わらないもの \\ 悪化 & 症状の悪くなったもの \\ 不明 & 受診しなくなったもの \end{aligned}


では 7 名中の 5 名 $(72 \%)$ に有効であり, 軽症 群と比較し重症群に有意な治療効果 $(\mathrm{p}<0.05)$ が得られた（表 5 ).

\section{考察}

咽喉頭異常感症は下咽頭癌, 頸部食道癌の 1 部分症状として生じてくることもあって，われ われはルーチン検査として食道ファイバー検査 を行っていたが，この際，同時に胃・十二指腸 を検査したところ比較的高率に粘膜病変を認め た。咽喉頭異常感症の合併疾患には胃疾患が多
表 5 咽喉頭異常感症患者の抗潰瘍剤による 臨床効果

\begin{tabular}{|c|c|c|}
\hline & 軽症群 21 名 & 监症群 7 名 \\
\hline 治痛 & 0 名 $(0 \%)$ & 1 名 (14\%) \\
\hline 改善 & 4 名 (19\%) 計 $19 \%$ & 4 名 ( $58 \%$ ) 計 $72 \%$ \\
\hline やや改善 & 2 名( 9\%) & 1 名 $(14 \%)$ \\
\hline 不変 & 10 名 ( $48 \%)$ & 0 名 $(0 \%)$ \\
\hline 悪化 & 2 名( 9\%) & 0 名 $(0 \%)$ \\
\hline 不明 & 3 名 $(15 \%)$ 計 $81 \%$ & 1 名( $14 \%$ ) 計 $28 \%$ \\
\hline
\end{tabular}

表 4 咽喉頭異常感症群 - 内科受診群の胃 - 十二指腸粘膜病変

\begin{tabular}{|c|c|c|}
\hline & 咽喉頭異常感症群 & 内科受診群 \\
\hline 正常群 & 29名（38.0\%） & 35名（38.5\%） \\
\hline 異常なし & 25名（32.8\%） & 25名（27.5\%） \\
\hline 胃ポリープ & 4名（5.2\%） & 2名（2.2\%） \\
\hline 萎縮性胃炎 & 0名（ $0 \% ）$ & 5名（5.5\%） \\
\hline 表層性胃炎 & 0名（ $0 \% ）$ & 3名 ( $3.3 \%)$ \\
\hline 軽症群 & 35名（46.0\%） & 33名（36.3\%） \\
\hline 胃潰瘍瘢痕 & $\begin{array}{c}5 \text { 名 }(6.5 \%) \\
\text { 食道炎合併 } 1 \text { 名 } \\
\text { びらん性胃炎合併 } 3 \text { 名 }\end{array}$ & 4名（ $4.4 \%)$ \\
\hline 十二指腸潰瘍般痕 & $\begin{array}{c}\text { 1名（1.5\%） } \\
\text { びらん性胃炎合併 } 1 \text { 名 }\end{array}$ & $\begin{array}{c}\text { 4名（ } 4.4 \%) \\
\text { びらん性胃炎合併 1名 }\end{array}$ \\
\hline 胃・十二指腸潰瘍瘢痕 & 1名 $(1.5 \%)$ & 1名（1.1\%） \\
\hline びらん性胃炎 & 28名（36.5\%） & $\begin{array}{c}23 \text { 名 }(25.3 \%) \\
\text { 胃ポリープ合併 } 1 \text { 名 } \\
\text { ロイコプラキフ合併 } 1 \text { 名 } \\
\text { 食道ポリープ合併 } 1 \text { 名 }\end{array}$ \\
\hline 重症群 & 10名（13.0\%） & 22名（24.2\%） \\
\hline 胃潰瘍 & $\begin{array}{c}\text { 6名（ } 7.7 \%) \\
\text { 十二指腸炎合併 } 2 \text { 名 }\end{array}$ & $\begin{array}{l}\text { 14名 }(15.4 \%) \\
\text { 十二指腸炎合併 } 1 \text { 名 } \\
\text { 食道炎合併 } 1 \text { 名 }\end{array}$ \\
\hline 十二指晹潰瘍 & 1名 $(1.5 \%)$ & 5名（ $5.5 \%)$ \\
\hline 病状胃炎 & 3名 $(3.8 \%)$ & 1名 ( $1.1 \%)$ \\
\hline 胃ガン & 0名（ $0 \%)$ & 2 名 ( $2.2 \%)$ \\
\hline その他 & 2名 ( $3.0 \%)$ & 1名 $(1.0 \%)$ \\
\hline 計 & 76名（100\%） & 91名（100\%） \\
\hline
\end{tabular}


いことは，過去の報告に散見されるが10111)，今 回，これまでに精神安定剤や消炎剂を投与して いても改善しなかった症例に検査を行ない, 㽸 状胃炎を認め, 抗潰瘍剤の投与で咽喉頭異常感 症が法とんど消失した症例に遭遇したことが, 今回の研究の発端となった。

\section{1. 年歯, 性別による検討}

一般に咽喉頭異常感症は30～50歳代の女性が 多いといわれている1114)。今回のわれわれの検 討でも 40～50歳代の女性が多く， ほぼ同様の結 果であった．ところが，胃・十二指腸粘膜病変 の程度からみると, 重症群は男性が女性の約 2 倍多く, 正常群は逆に女性が約 2 倍多く, 咽喉 頭異常感症群, 内科受診群ともに類似した性別, 年齢分布を示した（表 6,7 ）。胃潰瘍は 40～60 歳代の男性に多いと報告されているが15)，咽喉

表 6 咽喉頭異常感症群の性, 年龄分布

\begin{tabular}{|c|c|c|c|c|c|c|c|c|}
\hline & \multicolumn{2}{|c|}{ 正常群 } & \multicolumn{2}{|c|}{ 軽症群 } & \multicolumn{2}{|c|}{ 重症群 } & \multicolumn{2}{|c|}{ 総計 } \\
\hline & 男性 & 女性 & 男性 & 女性 & 男性 & 女性 & 男性 & 女性 \\
\hline $10-19$ 歲 & 1 & 0 & 0 & 0 & 0 & 0 & 1 & 0 \\
\hline $20-29$ & 2 & 0 & 4 & 1 & 2 & 0 & 8 & 1 \\
\hline $30-39$ & 1 & 2 & 3 & 3 & 0 & 0 & 4 & 5 \\
\hline $40-49$ & 0 & 6 & 3 & 5 & 2 & 1 & 5 & 12 \\
\hline $50-59$ & 2 & 6 & 3 & 2 & 2 & 2 & 7 & 10 \\
\hline $60-69$ & 3 & 3 & 4 & 4 & 0 & 0 & 7 & 7 \\
\hline $70-79$ & 1 & 2 & 1 & 2 & 1 & 0 & 3 & 4 \\
\hline $80-$ & 0 & 0 & 0 & 0 & 0 & 0 & 0 & 0 \\
\hline \multirow[t]{3}{*}{ 計 } & 10 & 19 & 18 & 17 & 7 & 3 & 35 & 39 \\
\hline & \multicolumn{2}{|c|}{29 名 } & \multicolumn{2}{|c|}{35 名 } & \multicolumn{2}{|c|}{10 名 } & \multicolumn{2}{|c|}{74 名 } \\
\hline & \multicolumn{2}{|c|}{$(38 \%)$} & \multicolumn{2}{|c|}{$(46 \%)$} & \multicolumn{2}{|c|}{$(13 \%)$} & & \\
\hline
\end{tabular}

表 7 内科受診群の性, 年齢分布

\begin{tabular}{|c|c|c|c|c|c|c|c|c|}
\hline & \multicolumn{2}{|c|}{ 正常群 } & \multicolumn{2}{|c|}{ 軽症群 } & \multicolumn{2}{|c|}{ 荲症群 } & \multicolumn{2}{|c|}{ 総計 } \\
\hline & 男性 & 女性 & 男性 & 女性 & 男性 & 女性 & 男性 & 女性 \\
\hline $10-19$ 歳 & 0 & 0 & 0 & 0 & 0 & 0 & 0 & 0 \\
\hline $20-29$ & 2 & 6 & 1 & 2 & 1 & 1 & 4 & 9 \\
\hline $30-39$ & 1 & 3 & 4 & 1 & 3 & 0 & 8 & 4 \\
\hline $40-49$ & 4 & 5 & 6 & 3 & 1 & 2 & 11 & 10 \\
\hline $50-59$ & 1 & 4 & 4 & 2 & 5 & 3 & 10 & 9 \\
\hline $60-69$ & 2 & 2 & 6 & 1 & 2 & 1 & 10 & 4 \\
\hline $70-79$ & 2 & 2 & 0 & 1 & 2 & 0 & 4 & 3 \\
\hline $80-$ & 0 & 1 & 1 & 1 & 0 & 1 & 1 & 3 \\
\hline \multirow[t]{3}{*}{ 計 } & 12 & 23 & 22 & 11 & 14 & 8 & 48 & 42 \\
\hline & \multicolumn{2}{|c|}{35 名 } & \multicolumn{2}{|c|}{33 名 } & \multicolumn{2}{|c|}{22 名 } & \multicolumn{2}{|c|}{90 名 } \\
\hline & \multicolumn{2}{|c|}{$(38.5 \%)$} & \multicolumn{2}{|c|}{$(36.3 \%)$} & \multicolumn{2}{|c|}{$(24.2 \%)$} & & \\
\hline
\end{tabular}

頭異常感症群でも，40～50歳代の男性に胃・十 二指腸病変の多かったことから，咽喉頭異常感 症を訴えて受診した患者で $40 ＼mathrm{~ 50 歳 代 の 男 性 患 ~}$ 者に技いては，胃・十二指腸病変の合併も考慮 する必要があると考えた。

\section{2. 粘膜病態による検討}

咽喉頭異常感症群と内科受診群の粘膜病変の 詳細を表 4 に示した. 内科受診群に重症群の多 いことは当然の結果であるが，咽喉頭異常感症 群に执いても13\%に重症群が認められ，その 7 割は潰瘍性病変であった。軽症群は内科受診群 に比して高率の $46 \%$ に病変を認めた. しかし， 健康人にも胃・十二指腸粘膜病変を有している 可能性があり，これら $13 \%$ と $46 \%$ の值が健康人 と比較して高いかどらかの問題が残った。 そこ で，正常者に括ける胃・十二指腸病変の有病率 を，集団健診の結果および剖検の報告を参考に して比較検討した.

内視鏡胃集団検診全国集計による胃潰瘍の発 見率は，昭和60年度から平成元年までにおいて

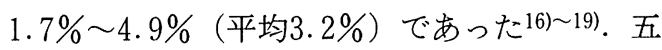
ノ井の剖検統計や検診統計を詳細に検討した結 果では, 日本人の胃潰瘍の有病率は $2 \sim 5 \%$ で あると考えられた ${ }^{15)}$. 検查方法や検查対象が異 なるため単純に比較することはできないが，今 回の咽喉頭異常感症群に拈ける胃潰瘍の発生頻 度は $7.7 \%$ であり（表 4), また片山らも咽喉頭 異常感症患者の $7.7 \%$ が胃潰瘍であったと, わ れわれとほぼ同様の結果を報告していることか ら 9), 咽喉頭異常感症患者の胃潰瘍合併頻度は 健康人と比較するとやや多いと考えた.

十二指腸潰瘍の発見率は, 内視鏡集団検診全 国集計には記載されておらず，各施設ごとの報 告では $1.1 \%$ ３.2\%と様々である2021). X 線撮 影による検診の全国集計で, 胃潰瘍の発見率は $1.5 \%$ 前後であり，また，十二指腸潰瘍の発見

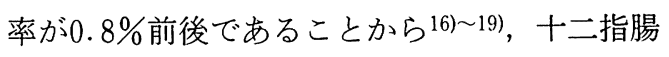
潰瘍の有病率は胃潰瘍の約半数程度と推測され る.これらの報告より, 十二指腸潰瘍の有病率 は胃潰瘍の有病率 $2 \sim 5 \%$ の半数の $1 \sim 2 \%$ と 
考えた。咽喉頭異常感症群での十二指腸潰瘍の 合併は 1 名の $1.5 \%$ だけであり, 今回の検討で 十二指腸潰瘍に関しては, 検診結果とほぼ同様 となり，咽喉頭異常感症に高率に認められる所 見ではないと考えた。

軽症群で多数を占めたびらん性胃炎は, 集団 検診に打ける頻度の報告が $14 \%{ }^{22)} \sim 44 \%{ }^{21)}$ と 様々である. 検者がどの程度の病変までを異常 と診断するかにより頻度の差が生じる可能性が あり, 他院との比較は困難であった。

当院で行った内科受診群との比較では, 咽喉 頭異常感症群は内科受診群よりびらん性胃炎の 頻度が高かった.内科受診群は何らかの消化管 的内科疾患を有している可能性が高く, 正常人 より当然, 胃・十二指腸粘膜疾患の率は高い. これらのことから, 咽喉頭異常感症患者は正常 人に比べて,びらん性胃炎の頻度が高いと推定 した。

\section{3 . 臨床的検討}

咽喉頭異常感症患者は偽薬だけでも約 $45 \%$ の 効果が認められるといわれている23)。今回, 咽 喉頭異常感症患者に拈ける胃・十二指腸病变を 認めた症例に対し，抗潰瘍剤を投与して症状の 経過を追い，原因疾患の一つになり得るか，可 能性の有無を検討した（抗潰瘍剂投与が可能で あった軽症群35名中 21 名, 重症群 10 名中 7 名).

一般に $\mathrm{H}_{2}$-blocker や粘膜保護剂などの抗潰 瘍剤は投与後, 約 1 週間で症状が改善してくる といわれている24) 27). そこで $1 \sim 2$ 週間投与 を原則とし，患者の自覚症状より効果を判定し たところ, 重症群は軽症群と比較して有意な効 果が得られた（表 5 ). 咽喉頭異常感症群の軽 症群に対する抗潰瘍剤の投与は, 偽薬としての 効果より悪く，抗潰瘍剤は無効と考えられたが, 重症群に対する抗潰瘍剤の投与は偽薬以上に明 らかに効果的であり，また，精神安定剤に対す る難治例に扣いても著明改善した症例も認めら れ, 効果的な薬剤と推察した。すなわち, 軽度 の胃粘膜病変では咽喉頭異常感を生じないが, 潰瘍や病状胃炎などの比較的高度の病变によっ
て生じる咽喉頭異常感症の存在が示唆された.

\section{4.これまでの報告による文献的考察}

咽喉頭異常感症の原因としての胃疾患は以前 より報告されているが6(12)，胃疾患のみを検討 した報告は極めて少ない。豊田らは咽喉頭異常 感症患者の約 $50 \%$ に上部消化管造影検査で胃下 垂を認めたと報告し，その機序に関しては交感 神経優位による自律神経失調が原因と述べてい $3^{778)}$. 片山らは, 咽喉頭異常感症患者116例に 上部消化管内視鏡検査を施行し，その粘膜病変 について表層性胃炎14例, 萎縮性胃炎113例, 病状胃炎10例, 残胃胃炎 2 例, 胃びらん 18 例, 胃潰瘍 9 例, 胃ポリープ 7 例, 胃ガン 2 例, 十 二指腸潰瘍 17 例, 十二指腸炎 2 例と報告してい るが，その機序は不明で, 自律神経の関与を示 唆している ${ }^{9)}$. 河辺らは咽喉頭異常感症患者の らち何らかの胃腸症状を訴えて胃カメラ検査を 施行した31例中25例に胃粘膜の異常を認めたと 報告して扣り13)，また咽喉頭異常感症患者の合 併疾患として高血圧と胃潰瘍が多い10), 女性の 咽喉頭異常感症患者に胃炎の合併が多(11)な どの報告もあるが，その関連性については述べ られていない。

今回われわれは胃・十二指腸疾患が咽喉頭異 常感を引き起こす機序を以下のように考えた. 咽喉頭異常感症の発症因子の一つには頸部食道 筋の機能異常, 咽喉頭, 食道, 頸部筋の過緊張

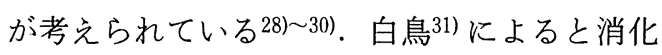
性潰瘍が発生した場合, 炎症や種々の刺激が胃 壁の筋層, 神経に直接作用し, 迷走神経を介す る局所反射や中枢性反射が起こり, 胃全体の緊 張度の増強と蠕動運動の方進がおこると報告し ているが, 迷走神経は咽喉頭部, 頸部食道へも また遠心性繊維を送っている32)。そこで，胃潰 瘍をはじめとした比較的高度の胃・十二指腸病 変がある場合, 胃壁からの刺激が迷走神経を介 した中枢性反射により胃だけではなく，咽喉頭 部, 頸部食道の諸筋群の緊張も引き起こし, 咽 喉頭異常感を招来しているものと考察した。

咽喉頭異常感症の治療薬として, 精神安定剂, 
消炎鎮痛剤, 筋弛緩薬, 種々の漢方薬の有効性 が報告されているが，その効果は約50７0\%の 間である11328)33)34)。 また，消炎鎮痛剤は胃潰瘍 やびらん性胃炎を悪化させることが多く35)，胃 疾患を合併する患者への投与は注意を要する. しかし, 胃潰瘍の約半数は無症候性潰瘍である といら報告にもあるように ${ }^{15)}$ ，胃疾患がある際 に必ずしも消化器症状の訴觉があるわけではな い.

今回われわれは, 抗潰瘍剤単独投与で, 精神 安定剤や消炎剂などのこれまでに報告されてい る薬剤に対しての無効例を含む重症群において, $70 \%$ 以上の有効率を認めた。 このことは, 従来 の薬剤治療において効果のない症例に対し上部 消化管内視鏡検査を行い, 胃 -十二指腸粘膜に 病変のあった場合, 試みるべき良い治療法であ ると考光た。

\section{まとめ}

1 ）咽喉頭異常感症患者に対して上部消化管 内視鏡検査により, 胃 - 十二指腸粘膜病变の検 討を行い，消化管疾患疑いの内科受診患者にお ける上部消化管内視鏡検査所見との比較検討を 行った.

2 ）男性の咽喉頭異常感症患者は, 胃・十二 指腸病変を認める割合が内科受診患者と同様に 多かった。

3 ) 咽喉頭異常感症患者で, 軽度胃 - 十二指 腸粘膜病変を持つ症例に, 抗潰瘍剤の投与は無 効であった。

4 ）精神安定剂や消炎剂無効の難治症例を含 む咽喉頭異常感症患者で, 高度, 胃 - 十二指腸 粘膜病変を持つ症例に対して, 抗潰瘍剤を投与 することにより $72 \%$ の改善以上の有効率を得た.

5 ）胃・十二指腸粘膜病変に上る咽喉頭異常 感症を生じる機序として, 病変部位刺激による 迷走神経の中枢反射の関与を推察した.

な拉, 本論文の要旨は第43回日本気管食道学会, 第66回日耳鼻東海地方部会連合講演会において口演 した.

\section{参考文献}

1）山際幹和, 坂倉康夫 : 咽喉頭異常感症 一その 要因としての上気道炎一。耳鼻臨床 補 $23: 79$ $\sim 84,1988$.

2) 石谷保夫, 小池靖夫 : 咽喉頭異常感症の診断的 治療. JOHNS 5 : 1124 1128, 1989.

3) 山際幹和, 福生治城, 西岡博之, 他: Sulpiride による咽喉頭異常感症の治療成績. 耳鼻臨床 $78: 1663 \sim 1673,1985$.

4）五十嵐博之：咽喉頭異常感症（主として自律神 経系へのアプローチ). 耳鼻臨床 $70: 1007$ 1010, 1977.

5）小川浩司：咽喉頭異常感症とアレルギー。 JOHNS 5 : 1089 1091, 1989.

6) 太田文彦：咽喉頭異常感の要因. JOHNS 5 : 1043 1048, 1989.

7）豊田 務, 和田秀一：咽喉頭の異常感と胃下垂. 日耳鼻 $67: 822,1964$.

8）豊田文一, 豊田 務, 和田秀一：咽喉頭神経症 と胃下垂. 日気食会報 $16: 129,1965$.

9）片山 修, 荒巻 元, 相沢晴子, 他 : 咽喉頭異 常感を契機として発見された胃病変の臨床的検 討. 日消病会誌 $82: 1238,1985$.

10）高安 次, 香取早苗, 香取公明, 他 : 咽喉頭異 常感の統計. 耳鼻臨床 補23:5〜17, 1988.

11）山際幹和, 北鼻正義, 福生治城, 他 : 咽喉頭異 常感症例の統計的観察. 耳鼻臨床 $79: 1823 \sim$ 1840, 1986.

12）井上鐵三 : 咽頭 - 喉頭 - 食道異物感症の成因に 関する一考察. 耳展 $21: 539 \sim 545,1978$.

13）河辺義孝, 近藤 隆 : 咽喉頭異常感に関する臨 床的観察 一とくに異常感患者の甲状腺機能に ついて一. 日気食会報 $18: 54 \sim 59,1967$.

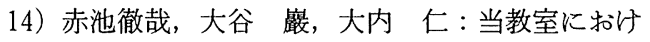
る咽喉頭異常感の統計的観察. 耳鼻臨床 78 : 983 989, 1985.

15）五ノ井哲朗：胃潰瘍の剖検頻度执よび日本人の 胃潰瘍有病率. 日本人の胃潰瘍一胃潰瘍なら びに胃潰瘍症の疫学一.13〜 46頁, 新興医学出 版社, 東京, 1977.

16）久道 茂, 土井偉誉, 岩崎政明, 他 : 昭和 61 年 度消化器集団検診全国集計. 消集検 $80: 106$ $120,1988$.

17）久道 茂, 土井偉誉, 岩崎政明, 他 : 昭和 62 年 
度消化器集団検診全国集計。消集検 $85 ： 180$ 201, 1989.

18）久道 茂, 土井偉誉, 岩崎政明, 他: 昭和 63 年 度消化器集団検診全国集計.消集検 $88 ： 110$ 131, 1990.

19）久道 茂, 土井偉誉, 岩崎政明, 他: 平成元年 度消化器集団検診全国集計. 消集検 $92: 150$ 168, 1991.

20）伊藤 毛, 望月福治：胃間接 $\mathrm{X}$ 線逐年受検群に 行った内視鏡検診の経験. 消集検 $84: 95 \sim 101$, 1989.

21）金城福則，池間 稔，大湾朝尚，他：胃集検を さらに発展させるためには一沖縄県離島にお。 ける上部消化管内視鏡集検成績の検討から一. 消集検 $87: 49 \sim 58,1990$.

22）竹田 一, 辻 俊三, 布施好信, 他 : 内視鏡単 独による出張胃集団検診. 消集検 $76: 70 \sim 75$, 1987.

23）古川浩三, 石井豊太 : 咽喉頭異常感症に対寸る 柴朴湯の治療効果 一Placebo との比較一. 耳 展 $31: 1111 \sim 1121,1988$.

24）三好秋馬, 田中恒男, 谷内 昭, 他: 急性胃炎 および慢性胃炎に伴う急性胃粘膜病変に対する Cimetidine の臨床的薬効評価 一二重盲検間比 較法による用量反応効果の検討一. 薬理と治療 $13: 6789 \sim 6806,1985$.

25）本望篤男, 前田秀人, 野嶋 豊: タガメット 発売後の臨床成績（第 2 報)。診と薬 $22: 269$ $\sim 283,1985$.

26）三好秋馬, 奥原種臣, 岸本真也, 他 : 消化器潰
瘍に対する Cetraxate の臨床効果. 内科宝函 $24: 105 \sim 115,1977$.

27）常岡健二, 市岡四象, 三輪 剛, 他: びらん, 出血, 発赤を主とする急性胃粘膜病変に対する Cetraxate の臨床的薬効評価 一多施設二重盲 検比較試験による内視鏡的検討一. 臨床評価 $10: 787 \sim 803,1982$

28）武藤次郎：咽喉頭異常感症に対するミオナール の効果. 耳展 $31: 1105 \sim 1110,1988$.

29）稲木匠子, 丘村 熙, 森 敏裕：食道透視と嚥 下圧測定よりみた咽喉頭異常感症の燕下機能. 耳鼻臨床 補 $23: 40 \sim 45,1988$.

30）川久保淳 : 下咽頭 - 食道之自律神経（臨床的観 察). 日気食会報 $19: 20 \sim 27,1968$.

31）白鳥常男：胃 - 十二指腸潰瘍之胃運動. 外科 MOOK (草間 悟, 和田達雄, 三枝正裕編). 26～31頁，金原出版，東京，1978.

32）山口 剛: 自律神経の生理学. JOHNS 5:795 $\sim 804,1989$.

33）山際幹和, 原田輝彦, 坂倉康夫 : 柴朴湯を用い た咽喉頭異常感症の治療. 耳鼻臨床 $84 ： 837 〜$ 851, 1991.

34）小林一女, 山本賢之, 調所廣之 : 获苓领合半夏 厚朴湯の咽喉頭異常感症の治療成績. 耳鼻臨床 $78: 1675 \sim 1680,1985$.

35）荻野 敏 : 非ステロイド消炎・鎮痛剂の副作用 之相互作用. JOHNS $6: 1059 \sim 1064,1990$.

$\left(\begin{array}{l}\text { 別刷請求先 : 坪川 操 } \\ \text { 厂9 } 10 \text { 福井市御幸2-20-25 }\end{array}\right)$ 